\title{
Peran Sekolah Peternakan Rakyat dalam Meningkatkan Nilai Tambah pada Peternak Sapi Potong di Kabupaten Muara Enim
}

\author{
The Role of Sekolah Peternakan Rakyat to Increase the Added Value of The Cattle Beef Local Farmer in \\ Muara Enim
}

\author{
H. C. Oktavia ${ }^{1}$, E.R. Cahyadi ${ }^{2}$, M. Syamsun ${ }^{2}$ \\ ${ }^{1}$ Mahasiswa Pascasarjana Jurusan Ilmu Manajemen, FEM IPB \\ ${ }^{2}$ Dosen Jurusan Ilmu Manajemen, FEM IPB \\ Departemen Manajemen FEM IPB \\ E-mail corresponden author: unaoktavia@gmail.com
}

\begin{abstract}
The gaps issue in the food commodity happens in Muara Enim District, the demand for beef were steadily increasing but it can't fulfilled by the amount of beef production in the area. In order to increase the quality, population and productivity that based on the local farmer, government decide to make an effort to increase local farmer business by establishing the Sekolah Peternakan Rakyat (SPR). The purpose of this research was to analyze the effect of SPR for the local farmer in Muara Enim by mapping beef cattle supply chain and analyzing the role of SPR to increase added value for local farmer in Muara Enim. Primary data was collected by conducting an interview to respondents with a questionnaire as its guidelines. The data was analyzed by Hayami method. The result of this research shows that the SPR farmer had more wide sale access compared to non SPR farmer and SPR farmer added value increase can be seen by the improvement of the cattle weight.
\end{abstract}

Keywords: Sekolah Peternakan Rakyat, added value, cattle beef supply chain, local farmer

\section{PENDAHULUAN}

Daging sapi memiliki peran yang besar dan memberikan andil dalam pemenuhan gizi masyarakat, khususnya protein hewani. Permasalahan yang terjadi pada komoditas daging sapi terkait dengan kesenjangan produksi dimana pertumbuhan permintaan bergerak lebih cepat dibandingkan dengan pertumbuhan penyediannya. Jumlah penduduk di Indonesia yang terus bertambah diikuti dengan perbaikan taraf hidup menggeser pola konsumsi masyarakat mengarah pada pemenuhan proten hewani. Kondisi ini tidak diimbangi dengan produksi sapi potong dalam negeri yang jumlahnya tidak dapat memenuhi kebutuhan konsumsi daging sapi di Indonesia (Priyanto 2011).

Kesenjangan produksi daging sapi dialami pula di Kabupaten Muara Enim. Permintaan daging sapi yang meningkat tidak bisa dipenuhi oleh jumlah produksi daging sapi di wilayah tersebut. Usaha sapi potong saat ini sebagian besar dilakukan peternak rakyat dengan skala usaha relatif kecil. Hal ini berkonotasi bahwa pendapatan dari ternak relatif rendah (Kusnadi 2008).

Usaha peternakan rakyat yang berada di Kecamatan Muara Enim dapat dikatakan masih belum berkembang. Menurut Saputra et al. (2009), permasalahan umum yang ditemui dalam pengembangan usaha sapi potong adalah bahwa peternakan rakyat memiliki karakteristik yang unik yaitu skala usaha yang kecil (3-5 ekor), masa produksi sapi potong yang relatif lama, sistem pemeliharaan masih cenderung dilakukan dengan pola tradisional (kawin alami) sehingga teknologi inseminasi buatan tidak diterapkan oleh semua peternak.

Kendala yang dihadapi oleh peternak sapi potong di Muara Enim adalah terbatasnya pengetahuan peternak mengenai cara beternak yang baik sehingga peternak lebih memilih beternak secara tradisional. Hal tersebut terlihat dari pemberian pakan ternak dengan pakan hijauan karena adanya keterbatasan alat atau mesin untuk mengolah pakan fermentasi. Keterbatasan akses peternak terhadap pasar dan informasi menyebabkan peternak tidak dapat menentukan harga jual ternak sapi potong secara benar. Harga daging sapi yang tinggi tidak menjadi sebuah indikasi permasalahan yang membuat margin keuntungan dalam tata niaga daging sapi tidak terdistribusi dengan baik (Rachman 2016).

Saptana (2017) dalam penelitiannya menyatakan bahwa untuk mendapatkan kinerja rantai pasok sapi potong yang efektif dan efisien perlu dilakukan analisis kinerja saluran rantai pasok. Analisis saluran rantai pasok dilakukan dengan mengidentifikasi dan menganalisis peran pelaku dalam rantai pasok sehingga dapat diidentifikasi permasalahan dan peran yang dijalankan masing-masng pelaku usaha dalam rantai pasok ternak dan daging sapi. Dibutuhkan suatu pemetaan yang jelas terkait jaringan 
distribusi pasokan daging sapi, agar dapat dilihat sejauh mana efisiensi rantai pasok daging sapi pada kedua kelompok peternak di Kabupaten Muara Enim.

SPR merupakan salah satu upaya yang dikerahkan pemerintah untuk membangun pola pikir peternak dalam melakukan usaha ternak. Diharapkan melalui kegiatankegiatan yang diberikan oleh SPR seperti pelatihan mengenai pembuatan pakan fermentasi, penyuluhan mengenai kesehatan ternak dan bantuan berupa alat-alat peternakan dapat mendukung keberhasilan SPR dalam melakukan peningkatan kesejahteraan peternak yang diikuti dengan peningkatan daya saing usahanya (Sekolah Peternakan Rakyat 2015). Melalui peran yang dimiliki oleh SPR diharapkan peternak sapi potong di Kabupaten Muara Enim dapat meningkatkan keuntungan melalui peningkatan nilai tambah.

Penelitian ini bertujuan untuk menganalisis peran SPR dalam pemetaan jaringan distribusi sapi potong dan peningkatan nilai tambah bagi peternak sapi potong di Kabupaten Muara Enim.

\section{MATERI DAN METODE}

\section{Waktu dan Tempat}

Penelitian ini dilaksanakan di Sekolah Peternakan Rakyat Muara Tigo Manunggal yang berada di Kabupaten Muara Enim, yang mencakup tiga desa yang berada dalam satu lingkup SPR yaitu desa Harapan Jaya, Muara Harapan dan Saka Jaya. Pemilihan lokasi dilakukan secara sengaja (purposive method) karena wilayah Muara Enim merupakan salah satu kota yang mendorong program pembentukan SPR. Kegiatan penelitian dan pengumpulan data dilakukan pada bulan Juli 2017.

\section{Metode Pengumpulan Data}

Metode yang digunakan untuk pengambilan data primer adalah Focus Group Discussion dan survey yang diarahkan untuk memperoleh informasi mendalam melalui observasi dan wawancara langsung kepada responden yang berada di SPR Muara Tigo Manunggal dengan dibantu panduan kuesioner. Peternak yang telah bergabung dengan SPR dan peternak non SPR menjadi responden dalam penelitian ini. Terdapat 52 peternak yang terbagi ke dalam 30 peternak anggota SPR dan 22 peternak non SPR.

\section{Metode Analisis}

Pola dan peta distribusi dalam rantai pasok daging sapi dari peternak hingga ke konsumen akhir dianalisis secara deskriptif. Analisis kuantitatif digunakan untuk menganalisis nilai tambah bagi peternak.

Dalam bidang pertanian, nilai tambah dapat disederhanakan sebagai nilai yang tercipta dari kegiatan mengubah input pertanian menjadi produk pertanian atau nilai yang tercipta dari kegiatan mengolah hasil pertanian menjadi produk akhir (Bantacut 2013).

Perhitungan analisis nilai tambah dilakukan dengan menggunakan metode Hayami dengan tujuan untuk mengetahui berapa besar margin yang diperoleh dari pelaku rantai pasok sapi potong di Kabupaten Muara Enim yaitu peternak. Marjin didapatkan dari selisih antara nilai output dengan harga input. Perhitungan nilai tambah produk dilakukan dengan mengkonversikan output dengan input berupa bobot badan sapi anakan:

Faktor konversi $(\mathrm{kg})=$

$$
\frac{\text { output (bobot badan sapi) }}{\text { input (bobot badan sapi anakan) }}
$$

Beberapa variabel yang terkait dalam analisis nilai tambah, yaitu:

1. Faktor konversi, menunjukkan banyaknya output yang dihasilkan dari satu satuan input

2. Koefisien tenaga kerja langsung menunjukkan tenaga kerja langsung yang diperlukan untuk mengolah satu satuan input

3. Nilai output, menunjukkan nilai output yang dihasilkan dari satu satuan input

Data-data yang diperlukan pada Metode Hayami untuk menghitung margin dari pelaku rantai pasok yaitu peternak berupa harga jual sapi $(\mathrm{Rp} / \mathrm{kg})$ dan bobot badan sapi untuk mengkonversi harga produk. Selain itu, dibutuhkan data mengenai biaya operasional yang dikeluarkan oleh setiap peternak yang terdiri dari biaya pakan hijauan, biaya pakan konsentrat dan biaya pemeriksaan kesehatan. Seluruh biaya yang dibutuhkan dikelompokkan pada satu tabel daftar biaya transaksi kedua kelompok peternak sapi potong.

Setelah mendapatkan hasil nilai tambah dari pelaku rantai pasok, maka dibandingkan nilai tambah peternak sapi potong yang merupakan anggota SPR dan peternak sapi potong non SPR untuk melihat apakah peternak yang merupakan anggota SPR memiliki nilai tambah lebih besar dibandingkan dengan peternak non SPR. Formulasi analisis nilai tambah dengan Metode Hayami dapat dilihat pada Tabel 1.

Penarikan kesimpulan dapat dilakukan dengan menjelaskan besarnya nilai tambah dan rasio keuntungan yang diterima pada pola rantai pasok daging sapi di Kabupaten Muara Enim. Adapun kriterianya adalah sebagai berikut :

a. Apabila nilai tambah lebih dari 0 artinya perlakuan mampu memberikan nilai tambah

b. Apabila nilai tambah $\leq 0$ maka perlakuan tersebut tidak mampu memberikan nilai tambah.

\section{HASIL DAN PEMBAHASAN}

\section{Sekolah Peternakan Rakyat}

Sekolah Peternakan Rakyat (SPR) merupakan hasil kerjasama antara Pemerintah Kabupaten Muara Enim melalui Dinas Peternakan dan Perikanan dengan Lembaga Penelitian dan Pengabdian kepada Masyarakat (LPPM) Institut Pertanian Bogor (IPB) yang dibentuk pada tahun 2015. Sekolah Peternakan Rakyat (SPR) dibentuk dengan tujuan memberikan ilmu pengetahuan kepada peternak berskala kecil tentang berbagai aspek teknis peternakan dan nonteknis yang melandasi terwujudnya perusahaan kolektif dalam satu manajemen untuk meningkatkan daya saing, pendapatan serta kesejahteraan peternak (Sentra Peternakan Rakyat 2015).

Pelaksanaan SPR di tingkat kabupaten/ 
Tabel 1. Analisis nilai tambah dengan menggunakan Metode Hayami

\begin{tabular}{|c|c|c|}
\hline No & Variabel & Nilai \\
\hline \multicolumn{3}{|c|}{ Output, Input dan Harga } \\
\hline 1 & Output (kg) & (a) \\
\hline 2 & Input bahan baku (kg) & (b) \\
\hline 3 & Input tenaga kerja (HOK) & (c) \\
\hline 4 & Faktor konversi & $(d)=(a) /(b)$ \\
\hline 5 & Koefisien TKL (HOK/kg) & $(\mathrm{e})=(\mathrm{c}) /(\mathrm{b})$ \\
\hline 6 & Harga output (IDR/kg) & (f) \\
\hline 7 & Rata-rata upah tenaga kerja (IDR/HOK) & $(\mathrm{g})$ \\
\hline \multicolumn{3}{|c|}{ Penerimaan dan keuntungan (IDR/Kg Bahan Baku) } \\
\hline 8 & Harga bahan baku (Rp/kg) & (h) \\
\hline 9 & Sumbangan input lain $(\mathrm{Rp} / \mathrm{kg})$ & (i) \\
\hline 10 & Nilai output (Rp/kg) & $(j)=(d) \times(f)$ \\
\hline \multirow[t]{2}{*}{11} & a. Nilai tambah $(\mathrm{Rp} / \mathrm{kg})$ & $(k)=(j)-(i)-(h)$ \\
\hline & b. Rasio nilai tambah (\%) & $(1)=(k) /(j) \times 100 \%$ \\
\hline \multirow[t]{2}{*}{12} & a. Imbalan tenaga kerja $(\mathrm{Rp} / \mathrm{kg})$ & $(\mathrm{m})=(\mathrm{e}) \times(\mathrm{g})$ \\
\hline & b. Bagian tenaga kerja (\%) & $(\mathrm{n})=(\mathrm{m}) /(\mathrm{k}) \times 100 \%$ \\
\hline \multirow[t]{2}{*}{13} & a. Keuntungan $(\mathrm{Rp} / \mathrm{kg})$ & $(\mathrm{o})=(\mathrm{k})-(\mathrm{m})$ \\
\hline & b. Tingkat keuntungan (\%) & $(p)=(o) /(j) \times 100 \%$ \\
\hline \multicolumn{3}{|c|}{ Balas Jasa dari Masing-Masing Faktor Produksi } \\
\hline \multirow[t]{4}{*}{14} & Marjin (Rp/kg) & $(q)=(j)-(h)$ \\
\hline & a. Imbalan tenaga kerja (\%) & $(\mathrm{r})=(\mathrm{m}) /(\mathrm{q}) \times 100 \%$ \\
\hline & b. Sumbangan input lain (\%) & $(s)=(i) /(q) \times 100 \%$ \\
\hline & c. Keuntungan (\%) & $(\mathrm{t})=(\mathrm{o}) /(\mathrm{q}) \times 100 \%$ \\
\hline 15 & $\mathrm{RC}$ rasio & $(\mathrm{u})=(\mathrm{j}) /(\mathrm{h})+(\mathrm{i})+(\mathrm{m})$ \\
\hline
\end{tabular}

Sumber: Hayami et al. (1987)

kota melibatkan berbagai pihak yang mendukung pengembangan SPR yang disusun menjadi satu kelembagaan yang dapat mengelola SPR. Untuk mencapai tujuan organisasi, diperlukan suatu susunan dan hubungan yang baik diantara setiap divisi-divisi pada organisasi tersebut yang digambarkan melalui sebuah struktur organisasi. Struktur organisasi Sekolah Peternakan Rakyat dirancang sangat sederhana yang intinya memberikan kekuasaan penuh kepada peternak yang direpresentasikan oleh Gugus Perwakilan Pemilik Ternak.

Kepengurusan Gugus Perwakilan Pemilik Ternak (GPPT) berjumlah 9 (sembilan) orang yang terdiri dari Ketua, Sekretaris, Bendahara dan 6 (enam) orang sebagai komisi. Penentuan komisi atau divisi dilakukan berdasarkan pertimbangan kondisi dan kepentingan SPR. SPR Muara Tigo Manunggal memiliki 6 (enam) divisi yang terdiri dari divisi Pemasaran, Produksi Ternak (IB), Kesehatan Hewan, Pemasaran, Relasi dan Humas serta divisi pengolahan hasil dan limbah ternak. Untuk menerapkan berbagai kebijakan strategis dan mengelola administarsi kegiatan SPR, GPPT menunjuk seorang manajer. Manajer SPR diutamakan lulusan peternakan atau kedokteran hewan, memiliki komitmen untuk mendampingi dan mendidik peternak, dan diseleksi oleh pihak akademisi dan pemerintah daerah. Struktur organisasi SPR dapat dilihat pada Gambar 1.

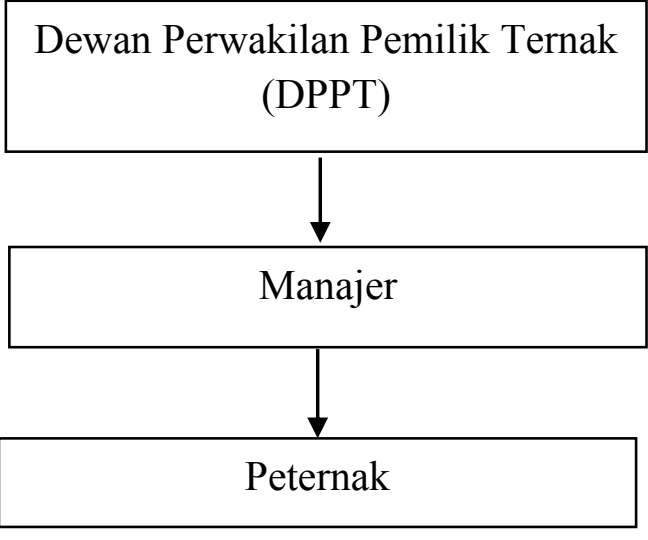

Gambar 1. Struktur organisasi SPR

\section{Jaringan Distribusi Rantai Pasok Sapi Potong di Kecamatan Muara Enim}

Pemetaan jaringan distribusi rantai pasok sapi potong di Kabupaten Muara Enim dilakukan dengan mengidentifikasi setiap pelaku yang terlibat dalam kegiatan rantai pasok sapi potong dan pola aliran yang terjadi pada rantai pasok sapi potong. Pelaku yang terlibat dalam rantai pasok sapi potong adalah, peternak yang terbagi kedalam 
kedua kelompok yaitu peternak SPR dan peternak non SPR, blantik desa dan blantik luar desa, tukang potong hewan, pedagang pengecer dan konsumen akhir yang terdiri dari ibu rumah tangga, hotel, restaurant, pengelola katering dan pedagang bakso. Chopra dan Meindl (2007) menyatakan bahwa rantai pasok memiliki sifat yang dinamis namun melibatkan tiga aliran yang konstan yaitu aliran informasi, produk dan keuangan. Menurut Marimin et al (2013), mekanisme rantai pasok produk pertanian secara alami dibentuk oleh para pelaku rantai pasok itu sendiri. Struktur jaringan distribusi rantai pasok sapi potong hidup dan daging sapi di Kecamatan Muara Enim dapat dilihat pada Gambar 2.
Pola aliran pada rantai pasok sapi potong hidup dan daging sapi menunjukkan adanya tiga aliran, yakni aliran produk, aliran informasi dan aliran keuangan. Aliran produk sapi potong hidup mengalir dari hulu ke hilir yakni berawal dari peternak hingga ke konsumen akhir, sedangkan aliran daging sapi potong berawal dari tempat pemotongan hewan hingga ke konsumen akhir. Aliran keuangan yang terjadi terbagi menjadi dua yaitu aliran keuangan dengan produk sapi hidup yang mengalir dari tempat pemotongan hewan hingga peternak sapi dan aliran keuangan dengan produk daging sapi yang mengalir dari konsumen daging sapi hingga tempat pemotongan hewan. Aliran informasi pada rantai pasok ini terjadi baik dari hulu ke hilir maupun



Gambar 2. Rantai pasok sapi potong dan daging sapi hidup di Kecamatan Muara Enim

Keterangan:

$\longrightarrow$ : aliran produk

$<-->$ : aliran informasi

$\longrightarrow$ : aliran keuangan 
sebaliknya.Informasi yang mengalir terkait dengan jumlah ketersediaan sapi hidup, jumlah permintaan, harga jual sapi hidup dan harga jual daging sapi.

Perbedaan aliran informasi terjadi pada kedua kelompok peternak, dimana peternak yang telah bergabung dengan SPR memiliki akses informasi penjualan ternak yang lebih luas dibandingkan dengan peternak non SPR. Melalui SPR, informasi mengenai penjualan ternak dari peternak dan informasi mengenai pencarian ternak oleh blantik dapat ditampung. SPR akan menyebarkan informasi tersebut ke setiap peternak anggota SPR yang ada di setiap desa. Hingga saat ini, salah satu peran SPR bagi peternak adalah sebagai tempat pertukaran informasi yang tidak terbatas hanya mengenai masalah pemeliharaan saja, namun juga terkait dengan proses jual beli. Tujuan dari pengelolaan rantai pasokan adalah memasok produk siap pakai secara tepat waktu, tepat jumlah, tepat biaya dan yang terpenting, tepat mutu, dengan cara yang paling efisien (Probowati 2011).

\section{Analisis Nilai Tambah pada Peternak Sapi Potong di Kabupaten Muara Enim}

Perhitungan nilai tambah dilakukan pada anggota rantai yang melakukan aktivitas pada bagian hulu yaitu peternak. Analisis dilakukan pada kedua kelompok yaitu peternak SPR dan peternak non SPR dengan menggunakan Metode Hayami. Hasil nilai tambah dari kedua kelompok peternak akan dibandingkan untuk melihat berapa persen nilai tambah yang didapat dari kedua kelompok peternak. Hasil perhitungan nilai tambah pada peternak dapat dilihat pada Tabel 2.
Berdasarkan hasil perhitungan nilai tambah pada peternak sapi potong pada kedua kelompok peternak yaitu peternak SPR dan peternak non SPR, menunjukkan hasil yang berbeda. Peternak SPR memberikan nilai tambah yang lebih tinggi sebesar Rp 21.961/kg. Hal tersebut terjadi karena terdapat perbedaan pada sumbangan input lain (biaya operasional) dan output yang merupakan pertambahan bobot badan sapi, dimana peternak SPR memiliki nilai yang lebih tinggi dibandingkan peternak non SPR pada jumlah input dan output. Biaya operasional yang lebih tinggi pada peternak SPR, dikarenakan penerapan sistem pemeliharaan yang lebih baik yang ditandai dengan adanya pengeluaran biaya untuk dua jenis pakan yaitu hijauan dan konsentrat serta biaya kesehatan hewan. Dari hasil analisa nilai tambah pada tingkat peternak dapat dilihat bahwa peternak SPR memiliki nilai tambah yang tinggi dengan rasio nilai tambah $24 \%$.

Sebelum melakukan perhitungan nilai tambah, hal yang perlu diperhatikan adalah mengidentifikasi biayabiaya transaksi yang dikeluarkan peternak selama masa pemeliharaan ternak. Biaya transaksi yang dikeluarkan oleh peternak SPR didapatkan lebih tinggi jumlahnya dibandingkan dengan peternak non SPR. Daftar biaya transaksi diantara kedua kelompok ternak dijelaskan pada Tabel 3.

Pada peternak, sapi awal yang dibeli berupa sapi pedet dengan bobot rata-rata berkisar $100 \mathrm{~kg}$ yang diasumsikan dipelihara selama tiga bulan. Perbedaan penerapan manajemen pemeliharaan ternak menjadi salah satu alasan perbedaan output yang dihasilkan. Fokus

Tabel 2 Analisis nilai tambah pada peternak sapi potong

\begin{tabular}{|c|c|c|c|}
\hline No & Variabel & Peternak SPR & Peternak non SPR \\
\hline \multicolumn{4}{|c|}{ Output, Input dan Harga } \\
\hline 1 & Output $(\mathrm{Kg})=(\mathrm{a})$ & 233 & 163 \\
\hline 2 & Faktor Konversi $=(\mathrm{b})=(\mathrm{a}) /(\mathrm{b})$ & 2,33 & 1,63 \\
\hline 3 & Harga Output $(\mathrm{IDR} / \mathrm{Kg})=(\mathrm{c})$ & 39379 & 41164 \\
\hline \multicolumn{4}{|c|}{ Penerimaan dan Keuntungan } \\
\hline & Harga beli sapi anakan & 6.000 .000 & 6.000 .000 \\
\hline & Bobot badan sapi anakan umur 1 tahun & 100 & 100 \\
\hline 4 & Harga input $(\mathrm{Rp} / \mathrm{Kg})=(\mathrm{d})$ & 60,000 & 60,000 \\
\hline \multirow[t]{5}{*}{5} & Sumbangan input lain (biaya operasional) & & \\
\hline & Biaya pakan hijauan (IDR/Kg) & 7875 & 5400 \\
\hline & Biaya pakan konsentrat (IDR/Kg) & 1417 & 0 \\
\hline & Biaya pemeriksaan kesehatan & 500 & 0 \\
\hline & Total biaya operasi $(\mathrm{IDR} / \mathrm{Kg})=(\mathrm{e})$ & 9792 & 5400 \\
\hline 6 & Nilai Output $(\operatorname{IDR} / \mathrm{Kg})=(\mathrm{f})=(\mathrm{b}) \times(\mathrm{c})$ & 91,753 & 67,097 \\
\hline \multirow[t]{2}{*}{7} & Nilai Tambah $(\operatorname{IDR} / \mathrm{Kg})=(\mathrm{g})=(\mathrm{f})-(\mathrm{e})-(\mathrm{h})$ & 21,961 & 1697 \\
\hline & Rasio nilai tambah $=(\mathrm{h})=(\mathrm{g}) /(\mathrm{f})$ & $24 \%$ & $3 \%$ \\
\hline \multirow[t]{2}{*}{8} & Keuntungan $(\mathrm{IDR} / \mathrm{Kg})=(\mathrm{i})=(\mathrm{g})$ & 21,961 & 1697 \\
\hline & Tingkat keuntungan $=(j)=(i) /(f)$ & $24 \%$ & $3 \%$ \\
\hline \multicolumn{4}{|c|}{ Balas Jasa Faktor Produksi (IDR/Kg Bahan Baku) } \\
\hline 9 & $\operatorname{Marjin}(\operatorname{IDR} / \mathrm{Kg})=(\mathrm{k})=(\mathrm{f})-(\mathrm{d})$ & 31,753 & 7097 \\
\hline
\end{tabular}


Tabel 3. Daftar biaya transaksi peternak SPR dan peternak non SPR

\begin{tabular}{|c|c|c|c|}
\hline No & Biaya Transaksi & Peternak SPR & Peternak non SPR \\
\hline 1 & Biaya pembelian sapi anakan & 6.000 .000 & 6.000 .000 \\
\hline \multirow[t]{18}{*}{2} & Bobot badan sapi anakan & $100 \mathrm{~kg}$ & $100 \mathrm{~kg}$ \\
\hline & Biaya pakan hijauan (Peternak SPR) & 7875 & \\
\hline & Biaya tenaga kerja untuk mencari pakan per hari $=$ Rp 50.000 & & \\
\hline & Pakan rumput yang diperoleh per hari $=100 \mathrm{~kg}$ & & \\
\hline & Porsi kebutuhan pakan hijauan ternak & & \\
\hline & $(10 \% \times 175)=17,5 \mathrm{~kg}$ & & \\
\hline & Biaya pakan konsentrat (Peternak SPR) & 1417 & \\
\hline & Harga pakan konsentrat $=\mathrm{Rp} 45000$ & & \\
\hline & Jumlah pakan konsentrat $=75 \mathrm{~kg}$ & & \\
\hline & Porsi kebutuhan pakan konsentart bagi ternak $(1,5 \% \times 175 \mathrm{~kg})=2,625 \mathrm{~kg}$ & & \\
\hline & Asumsi pemeliharaan selama 90 hari & & \\
\hline & Biaya pemeriksaan kesehatan & 500 & \\
\hline & Biaya pakan hijauan (Peternak non SPR) & & 5400 \\
\hline & Biaya tenaga kerja untuk menggembalakan sapi Rp $30.000 / 5$ ekor sapi & & \\
\hline & Bobot sapi $(100 \mathrm{~kg} \times 5$ ekor sapi $)=500 \mathrm{~kg}$ & & \\
\hline & Biaya pemeriksaan kesehatan & & 0 \\
\hline & Biaya pakan konsentrat & & 0 \\
\hline & Asumsi pemeliharaan selama 90 hari & & \\
\hline Total & & 9792 & 5400 \\
\hline
\end{tabular}

utama dalam usaha beternak adalah manajemen pakan dan perawatan. Selain pemberian pakan hijauan, cara yang dapat dilakukan untuk mempercepat penggemukan ternak adalah dengan mengkombinasikan pakan hijauan dan pakan konsentrat. Hasil penelitian Sari et al. (2016) yang menyatakan bahwa pemberian pakan hijauan dan pakan tambahan berpengaruh terhadap penampilan sapi Bali, yaitu meningkatkan konsumsi pakan, menaikkan bobot badan dan menurunkan nilai konversi pakan sapi Bali. Selain itu, Mayulu et al. (2010) menyatakan bahwa faktor ketersediaan pakan melalui industri pakan menjadi salah satu pendukung dalam pengembangan usaha sapi potong dengan mengoptimalkan pemanfaatan bahan pakan spesifik lokasi melalui pola yang terintegrasi.

Peternak SPR menerapkan sistem pemeliharaan dengan cara dikandangkan, sehingga ternak sapi mendapatkan pemberian pakan hijauan dan konsentrat secara insentif. Berbeda halnya dengan peternak non SPR yang lebih banyak menggembalakan ternak sapinya di padang rumput untuk mencari pakan sendiri.

\section{KESIMPULAN}

Berdasarkan hasil pemetaan jaringan distribusi rantai pasok sapi potong pada kedua kelompok peternak, terdapat perbedaan aliran informasi yang dilalui. Peternak SPR mendapatkan pertukaran informasi untuk melakukan transaksi penjualan melalui SPR. Peternak SPR memiliki akses penjualan yang lebih luas dibandingkan peternak non SPR. Melalui SPR peternak berpeluang mengakses pasar di dalam dan luar desa. Peningkatan nilai tambah terjadi pada peternak SPR melalui perbaikan bobot dan kualitas ternak, sehingga dapat disimpulkan bahwa peran SPR dalam memberikan pembelajaran bagi peternak melalui penyuluhan dan pelatihan mengenai manajemen pemeliharaan dapat meningkatkan nilai tambah melalui peningkatan bobot badan sapi.

\section{IMPLIKASI MANAJERIAL}

Berdasarkan pembahasan dan hasil analisis dalam penelitian ini terdapat implikasi manajerial yang berkaitan dengan tujuan penelitian yang telah ditentukan sebelumnya. Peran SPR dalam meningkatkan nilai tambah bagi peternak SPR hanya meningkatkan bobot badan sapi. Bobot badan sapi yang meningkat didapatkan dari sistem pemeliharaan yang baik. Pelatihan dan penyuluhan yang diberikan oleh SPR baru bisa direalisasikan sampai pada tahap cara beternak yang baik oleh peternak. Maka untuk mempertahankan dan meningkatkan kemampuan peternak diperlukan pelatihan dan pendampingan secara intensif dari pihak SPR dan Pemerintah daerah terkait teknis manajemen pemeliharaan seperti penanganan terhadap penyakit dengan mengenali jenis-jenis penyakit ternak, sistem reproduksi menggunakan Inseminasi Buatan (IB) dan dari segi teknologi peternak bisa mendapatkan pelatihan mengenai teknologi pembuatan pakan fermentasi dan konsentrat. Selain aspek teknis manajemen pemeliharaan, penyuluhan mengenai strategi pengembangan usaha juga harus diberikan kepada peternak oleh tim SPR melalui diskusi yang dilakukan oleh peternak didampingi dengan pihak akademisi dengan tujuan perubahan pola pikir peternak untuk meningkatkan 
usahanya agar berorientasi bisnis sehingga dapat meningkatkan keuntungan dari nilai tambah tidak hanya dari peningkatan bobot badan saja.

\section{DAFTAR PUSTAKA}

Bantacut T. 2013. Pembangunan ketahanan ekonomi dan pangan pedesaan mandiri berbasis nilai tambah. Jurnal Pangan. 22(2): 397-406.

Chopra S, Meindl P. 2007. Supply Chain Management, Strategy, Planning, and Operations Third Edition. New Jersey (US): Pearson Education, Inc.

Hayami Y, Kawagoe T, Morooka Y, Siregar M. 1987. Agricultural Marketing and Processing in Upland Java. A Perspective from a Sunda Village. Bogor (ID): The CPGRT Centre.

Kusnadi U. 2008. Inovasi teknologi peternakan dalam sistem integrasi tanaman-ternak untuk menunjang swasembada daging sapi. Pengembangan Inovasi Pertanian. 1(3): 189-205.

Marimin, Djatna T, Suharjito, Hidayat S, Utama DN, Astuti R, Martini S. 2013. Teknik dan analisis pengambilan keputusan fuzzy dalam manajemen rantai pasok. Bogor (ID): IPB Press.

Mayulu H, Sunarso, Sutrisno I, Sumarsono. 2010. Kebijakan pengembangan peternakan sapi potong di Indonesia. Jurnal Litbang Pertanian. 29(1): 38-41.

Priyanto D. 2011. Strategi pengembangan usaha ternak sapi potong dalam mendukung program swasembada daging sapi dan kerbau tahun 2014. Jurnal Litbang Pertanian. 30(3): 108-116.

Probowati DB. 2011. Perancangan model rantai pasok agroindustri kelapa terpadu dalam usaha kecil. [Tesis]. Bogor (ID): Institut Pertanian Bogor.

Rachman NM. 2016. Efisiensi jaringan distribusi rantai pasok sapi di kota Bogor. [Tesis]. Bogor (ID): Institut Pertanian Bogor.

Saptana NI. 2017. Manajemen rantai pasok komoditas ternak dan daging sapi. Analisis Kebijakan Pertanian. 15(1): 83-39.

Saputra H, D Arief, Hendrawan DS. 2009. Strategi pengembangan ternak sapi potong berwawasan agribisnis di provinsi Aceh. Jurnal Manajemen dan Agribisnis. 6(2): 152-162.

Sari DDK, MH Astuti, LS Asi. 2016. Pengaruh pakan tambahan berupa ampas tahu dan limbah bioethanol berbahan singkong (Manihot utilissima) terhadap penampilan sapi bali (Bos sondaicus). Buletin Peternakan. 40(2): 107-112.

[SPR] Sentra Peternakan Rakyat. 2015. Buku Panduan Sekolah Peternakan Rakyat. Bogor (ID): Lembaga Penelitian dan Pengabdian kepada Masyarakat Institut Pertanian Bogor. 